\title{
The effect of fast created inbreeding on litter size and body weights in mice
}

\author{
Marte HolT*, Theo MEUwissen, Odd VANGEN \\ Department of Animal and Aquacultural Sciences, University of life sciences, \\ 1432 Ås, Norway
}

(Received 7 September 2004; accepted 24 March 2005)

\begin{abstract}
This study was designed to reveal any differences in effects of fast created versus total inbreeding on reproduction and body weights in mice. A line selected for large litter size for 124 generations $(\mathrm{H})$ and a control line $(\mathrm{K})$ maintained without selection for the same number of generations were crossed (HK) and used as a basis for the experiment. Within the HK cross, full sib, cousin or random mating were practised for two generations in order to create new inbreeding $\left(\mathrm{IB}_{\mathrm{F}}\right)$ at a fast rate. In the first generation of systematic mating, old inbreeding was regenerated in addition to creation of new inbreeding from the mating design giving total inbreeding $\left(\mathrm{IB}_{\mathrm{T}}\right)$. The number of pups born alive $(\mathrm{NBA})$ and body weights of the animals were then analysed by a model including both $\mathrm{IB}_{\mathrm{T}}$ and $\mathrm{IB}_{\mathrm{F}}$. $\mathrm{Th} \mathrm{IB}_{\mathrm{T}}$ of the dam was in the present study found to reduce the mean NBA with $-0.48( \pm 0.22)(\mathrm{p}<0.05)$ pups per $10 \%$ increase in the inbreeding coefficient, while the additional effect of $\mathrm{IB}_{\mathrm{F}}$ was $-0.42( \pm 0.27)$. For the trait NBA per female mated, the effect of $\mathrm{IB}_{\mathrm{T}}$ was estimated to be $-0.45( \pm 0.29)$ per $10 \%$ increase in the inbreeding coefficient and the effect of $\mathrm{IB}_{\mathrm{F}}$ was $-0.90( \pm 0.37)(\mathrm{p}<0.05)$ pups. In the present study, only small or non-significant effects of $\mathrm{IB}_{\mathrm{F}}$ of the dam could be found on sex-ratio and body weights at three and six weeks of age in a population already adjusted for $\mathrm{IB}_{\mathrm{T}}$.
\end{abstract}

fast inbreeding / mouse / litter size / body weight / inbreeding depression

\section{INTRODUCTION}

Inbreeding depression exists essentially in all populations and for almost all characters [12]. Knowledge of the effects of inbreeding on fitness is therefore important for animal breeding and evolutionary and conservation biology. There are several causes for inbreeding depression, but the most important source seems to be recessive or partially recessive deleterious effects of alleles [8]. The degree of inbreeding depression can be highly variable [3,20] and

*Corresponding author: marte.holt@ norsvin.no

Present address: Marte Holt, Po.box 504, 2304 Hamar, Norway 
has by several authors been indicated to be due to the level of previous inbreeding in the population $[10,13,19]$. Slow inbreeding can reduce the inbreeding depression by removing lethal or detrimental alleles of large effect from the population. When the genetic load of an animal is exposed by inbreeding, natural selection may have an enhanced opportunity to purge deleterious alleles from the population $[27,31,32]$. If slow inbreeding is conducted, natural selection has more time to act, and slow inbreeding should result in less inbreeding depression because deleterious alleles may have been purged from the population $[9,21,22]$. Populations, which have undergone inbreeding at a low rate, should therefore possibly show less inbreeding depression compared to populations that have been inbred at a high rate. The rate of inbreeding has been found to affect the inbreeding depression both in the housefly [10] and the Drosophila [1, 11,27].

Even though earlier studies have indicated that earlier inbreeding in a population affects the inbreeding depression caused by new inbreeding, no conclusive report has yet been given on the topic. The aim of the present study was therefore to test any possible differences between the effects of newly (mainly fast) created inbreeding and total level of inbreeding on reproductive performance and body weights in mice. The animals in the present study had its origin in a high line $(\mathrm{H})$ selected 124 generations on large first parity litter size and a control line $(\mathrm{K})$ maintained without selection for the same number of generations. Because of slowly accumulated inbreeding over many generations, the $\mathrm{H}$ and $\mathrm{K}$ lines are valuable resources for this study.

\section{MATERIALS AND METHODS}

\subsection{Selection history}

The mice used in the present study originated from two lines of mice that had been maintained for 124 generations of selection. The high line $(\mathrm{H})$ had been selected on a large number of pups born alive (NBA), and the control line $(\mathrm{K})$ had been maintained with random selection in all generations. Selection was based on family information, with on average two females and two males selected from the best 50 percent of the litters (randomly in the $\mathrm{K}$ line). The selected parents were mated at random, but mating of full sibs, half sibs and cousins were avoided. Litter size was standardised to eight pups within $24 \mathrm{~h}$ after birth when larger than eight in all lines, except for the period with studies of maternal effects in the high lines [30]. For further details of the selection history, see Joakimsen and Baker [18] and Vangen [29, 30]. 
The population size in each line varied between $40-75$ breeding females per generation and inbreeding increased with between $0.3-1.2$ percentage units per generation. The $\mathrm{H}$ and $\mathrm{K}$ lines are linked through a common base population (generation 0). A Dutch high line was introduced to the $\mathrm{H}$ line in generation 20, and this together with two periods of randomisation caused the total level of inbreeding in the $\mathrm{H}$ line to be lower compared to the $\mathrm{K}$ line. The $\mathrm{K}$ line was kept as a closed line for all generations.

\subsection{Animals}

The animals in the present study were sampled from two generations (124 and 125) to increase the number of animals in the study (Replicate 1 and 2). The mean NBA of the two generations was 23.1 (Standard deviation $\left.\left(\mathrm{sd}_{\mathrm{p}}\right)=4.0\right)$ in the $\mathrm{H}$ line and $11.5\left(\mathrm{sd}_{\mathrm{p}}=2.6\right)$ in the $\mathrm{K}$ line. The mean inbreeding coefficient of the two generations was $39 \%$ in line $\mathrm{H}$ and $65 \%$ in line $\mathrm{K}$. The mice were kept in cages of $30 \times 12.5 \times 12.5 \mathrm{~cm}^{3}$ and had free access to pellet concentrate and water. The lights were on for $16 \mathrm{~h}$ and off for $8 \mathrm{~h}$, and the ambient temperature was standardised to $23{ }^{\circ} \mathrm{C}$.

\subsection{Experimental design}

The design of the study is presented in Figure 1. The $\mathrm{H}$ and the $\mathrm{K}$ lines were crossed to give an HK group where all animals had an equal level of inbreeding close to zero, since the $\mathrm{H}$ and the $\mathrm{K}$ lines had been kept as separate populations for 124 generations. Within the HK cross, fullsib (FS), cousin (C) or random (R) mating was practised for two generations in order to create new inbreeding at a mainly fast rate $\left(\mathrm{IB}_{\mathrm{F}}\right)$. By crossing the $\mathrm{H}$ and $\mathrm{K}$ lines and then adopting the three mating schemes in the following generations, different levels of inbreeding would be represented within the same generation.

From generation 124 and 125 of the long-term selection study, 2-4 males and 2-3 females were randomly sampled from each of 35 families in the $\mathrm{H}$ and the $\mathrm{K}$ lines. The females from the $\mathrm{H}$ line were mated at random with males from the $\mathrm{K}$ line and vice versa, in order to give a cross named HK in Replicate 1 (Fig. 1). From the HK cross, 1-2 females and males were picked at random from 100 random litters to give the parent pairs for the next generation. Since the line from which the dam originated ( $\mathrm{H}$ or $\mathrm{K}$ ) probably had an influence on the performance of the offspring, half of the litters from which 


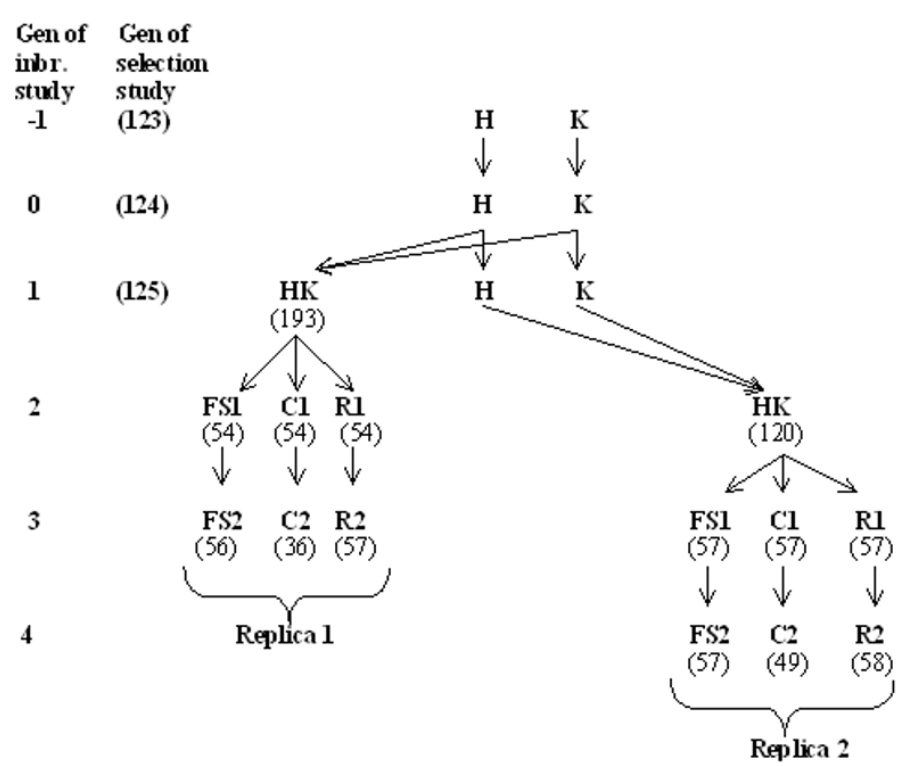

Figure 1. Experimental design of the study. The $\mathrm{HK}$ is the cross of the $\mathrm{H}$ and the $\mathrm{K}$ line and was used to breed three groups of offspring mated either my fullsib (FS), cousin $(\mathrm{C})$ or random $(\mathrm{R})$ mating for two generations. The numbers of mated females per group are given in brackets.

the offspring were chosen had a dam from the $\mathrm{H}$ line and half of the litters had a dam from the $\mathrm{K}$ line. The offspring kept from the HK cross were equally allocated to three new groups bred for two generations: An FS group bred with full sib mating, a $\mathrm{C}$ group based on mating of cousins and an $\mathrm{R}$ group maintained with random mating but with mating of full sibs and cousins avoided (Fig. 1). R then served mainly as a "control" measuring the inbreeding which was re-established from the line history by random mating. Each line had about 54 breeding females per generation. From half of the litters born in the FS, C and $\mathrm{R}$ groups, 2 males and 2 females were at random chosen to be parents for the next generation. Both litters and offspring within litters were chosen at random, but about half of the litters had a grandmother from the $\mathrm{H}$ line and the other half had a grandmother from the $\mathrm{K}$ line. Because of problems with recruiting enough animals that were cousins in the $\mathrm{C}$ group, the number of breeding females in the second generation of this group was reduced to 36 (Fig. 1). In Replicate 2, the numbers of breeding pairs in the HK cross were reduced to 120 , since Replicate 1 had proved a high rate of successful matings. 
The number of breeding pairs in each group was about 57. As for Replicate 1, the number of breeding females in the second generation of the $\mathrm{C}$ group was reduced, due to problems with recruiting enough animals that were cousins in this group. All animals were at least eight weeks old when mated.

\subsubsection{Measured traits}

Body weight at mating (BWM), NBA, number of pups born alive per mated female (NBAM), sex ratio and three week weights (BW21) of the offspring were recorded on all animals in the study. As in all generations of the whole selection experiment, BW21 were recorded as the average within each sex and litter. Due to limitations in the number of boxes that could be kept in the mouse laboratory, individual six week body weights (BW42) were recorded on only half of the litters. The animals that were weighed at six weeks were chosen at random. Only data from the two generations of systematic mating in the FS, $\mathrm{C}$ and $\mathrm{R}$ group in each replicate were used for the analyses. The generations analysed were generations 2 and 3 in Replicate 1 and 3 and 4 in Replicate 2. In total, we had 1205 observations on NBA, 1209 records on BW21, and 1283 records on BW42.

\subsection{Statistical analysis}

In this study, both overall inbreeding $\left(\mathrm{IB}_{\mathrm{T}}\right)$ and $\mathrm{IB}_{\mathrm{F}}$ were included in the model in order to reveal any differences in the effects of fast created versus total inbreeding. A complete pedigree covering 57433 individuals back to the base population was available, so the exact inbreeding coefficients of all animals in the study could be estimated. The inbreeding coefficients were estimated by a programme written by John James, University of Sydney, Australia (J. James, unpublished).

Data were analysed with an animal model, using ASReml [14]. Because of a high correlation between body weights of the dam and NBA [15], two different models were evaluated for the traits NBA and NBAM: one excluding (Model 1) and one including (Model 2) the body weight of the dam.

$$
Y=\mu+g e n+I B_{T}+I B_{F}+\text { dam }+ \text { error } \quad(\text { Model 1) }
$$


where

$Y$ is the trait analysed: either NBA or NBAM,

$\mu$ is the general mean,

gen is the effect of generation number of the inbreeding study

(generation 2-4),

$\mathrm{IB}_{\mathrm{T}}$ is the total inbreeding of the dam,

$\mathrm{IB}_{\mathrm{F}}$ is new inbreeding of the dam, caused by systematic mating,

dam is a random effect of the dam, linked to a pedigree,

error is the residuals.

Model 2 was the same as Model 1 but also included BWM.

The effects gen, $\mathrm{IB}_{\mathrm{T}}, \mathrm{IB}_{\mathrm{F}}$ and $\mathrm{BWM}$ were considered as fixed, whereas dam was random. The effects of $\mathrm{IB}_{\mathrm{T}}, \mathrm{IB}_{\mathrm{F}}$ and $\mathrm{BWM}$ were treated as regression variables, while gen was treated as a class effect. The effect of the line from which the dam originated (line $\mathrm{H}$ or line $\mathrm{K}$ ) was tested in a preliminary model, but was not significant and was therefore excluded from the model. A confounding between the inbreeding of the dam and inbreeding of the offspring made it impossible to include both. In order to distinguish maternal inbreeding from inbreeding of the offspring, a special mating scheme is needed (for an example, see Margulis [24]). Since maternal inbreeding is expected to affect litter size most (and maternal qualities are the most sensitive characters to inbreeding depression [12]), we chose to analyse the NBA, the NBAM and sex ratio with the inbreeding of the dam as a fixed effect.

The effect of BWM was included in Model 2, because there is a high realised genetic correlation between body weight of the dam and NBA [15]. The percentage of males born in the litter were analysed only by Model 2. For the analysis of NBAM, all animals that were mated and did not produce a litter were given a litter size value of zero.

The traits NBA and NBAM were also analysed by Model 1 and Model 2 with the effect of $\mathrm{IB}_{\mathrm{F}}$ excluded from the models. The percentage of males in the litter was analysed by Model 2 with the effect of $\mathrm{IB}_{\mathrm{F}}$ excluded from the model.

For the analysis of BW21 of the offspring, the following model was used:

$\mathrm{BW} 21=\mu+$ gen + sex $+B W M+$ weaned $+I B_{T}+I B_{F}+$ litter + error 
where

weaned is the weaned number of pups at weaning (day 21),

litter is a random effect of the litter in which the animal is born, linked to a pedigree.

The effects weaned and sex were treated as fixed effects with weaned treated as a regression variable and sex treated as a class variable. The other factors are as described for Model 1 and Model 2.

The analysis of BW42 was performed with Model 3, except that the factor weaned was found to be non-significant and was excluded from the model.

For BW21 and BW42, the corresponding models with $\mathrm{IB}_{\mathrm{F}}$ of the dam excluded from the model were also analysed.

In order to test how the inbreeding of the dam affected her own body weights (BWM), the following model was analysed:

$$
\mathrm{BWM}=\mu+\text { gen }+I B_{T}+I B_{F}+\text { dam }+ \text { error } \quad(\text { Model 4) }
$$

\section{RESULTS}

Figure 2 gives the expected level of $\mathrm{IB}_{\mathrm{F}}$ of the offspring in the two replicates in the study. The differences between groups are a function of the three mating designs: full sib (FS), cousin (C) and random (R) mating. The $\mathrm{IB}_{\mathrm{F}}$ created in group $\mathrm{R}$ is caused by the limited population size.

Figure 3 presents the mean $\mathrm{IB}_{\mathrm{T}}$ of the offspring in the study estimated from a pedigree back to the base population. Since the $\mathrm{H}$ line and the $\mathrm{K}$ line have not been linked for more than 120 generations, all offspring from the HK cross have an inbreeding coefficient of almost zero. In group $\mathrm{R}$, the level of the expected $\mathrm{IB}_{\mathrm{F}}$ is very low (Fig. 2), so almost all inbreeding in this group is caused by regeneration of old inbreeding. The level of old inbreeding influences the level of new inbreeding that is generated in the FS, C and R groups. Therefore, the difference in inbreeding level between the FS group and the R group in generation 126 in Figure 2 is smaller than the corresponding difference found in Figure 3.

Table I gives the number of observations, means and standard deviations for the reproductive performance and BWM (in grams) of the females used to produce $F_{1}-R_{1}$ and $F_{2}-R_{2}$ (Fig. 1). The effect of the replicate was nonsignificant, so the replicates are presented together. As can be seen from Table I, there are differences between some of the groups of offspring within generations for the traits NBA and NBAM. There are no differences between 


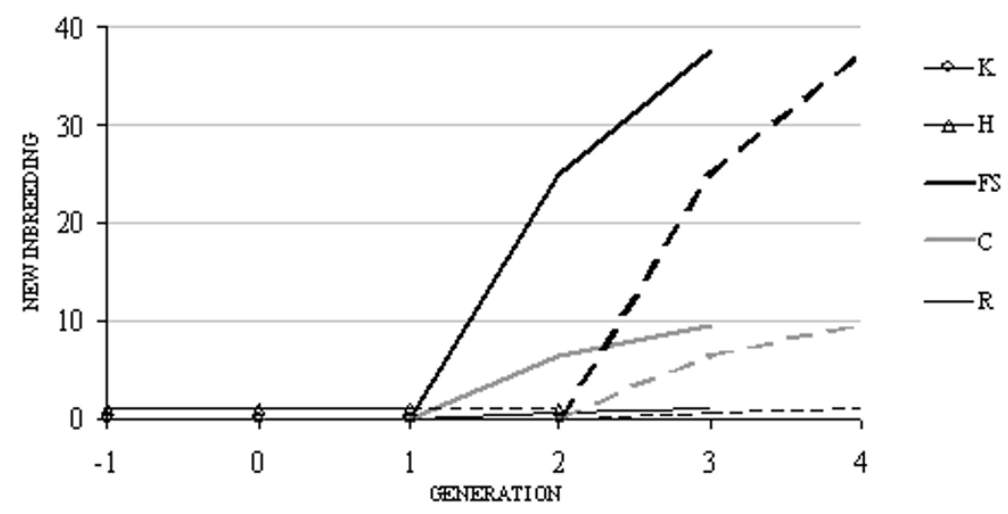

Figure 2. Expected new inbreeding of the offspring in the different groups in the two Replicates of the study. Solid lines represent Replicate 1, dashed lines represent Replicate 2.

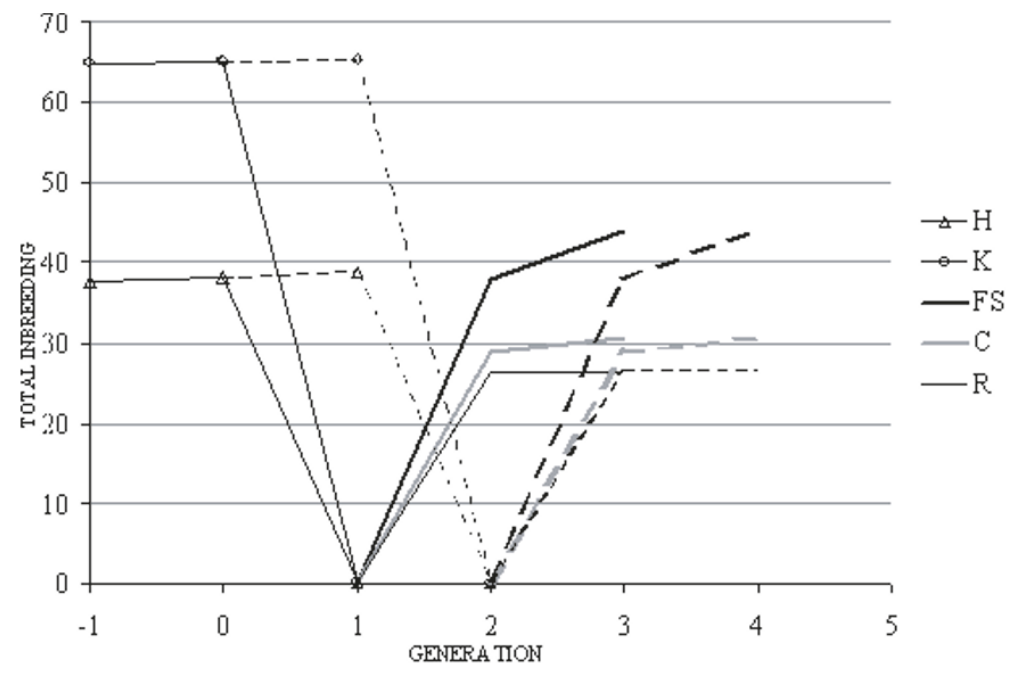

Figure 3. Mean total inbreeding of the offspring in the different groups in the two Replicates of the study, estimated from a pedigree back to the base population. Solid lines represent Replicate 1, dashed lines represent Replicate 2.

FS1, C1 or R1 for the trait NBA, but there is a difference between the groups for the trait NBAM as the FFM decreases. There is also a significant lower NBA in the FS2 groups and an even clearer trend for NBAM since NBA and FFM seem to be effected by the stronger inbreeding in this group.

The frequency fertile matings (FFM), estimated as the percentage of mated females that produced a litter (litters with all pups stillborn were included), 
Table I. Mean number of pups born alive (NBA), NBA per mated female (NBAM), frequency fertile matings (FFM), percentage males in the litter and body weight of the dam at mating $(\mathrm{BWM})$ in grams $(\mathrm{g})$ with standard deviations $\left(\mathrm{sd}_{\mathrm{p}}\right)$ for the females producing the different groups of offspring. The means include both Replicate 1 and Replicate 2. $\mathrm{N}=$ number of females that produced a litter.

\begin{tabular}{cccccccccccc}
\hline $\begin{array}{c}\text { Parental } \\
\text { group }\end{array}$ & $\begin{array}{c}\text { Group } \\
\text { offspring }\end{array}$ & $\mathrm{N}$ & $\mathrm{NBA}$ & $\mathrm{sd}_{\mathrm{p}}$ & $\mathrm{NBAM}$ & $\mathrm{sd}_{\mathrm{p}}$ & $\begin{array}{c}(\%) \\
\% \text { males }\end{array}$ & $\mathrm{sd}_{\mathrm{p}}$ & $\begin{array}{c}\mathrm{BW}) \\
\left(\mathrm{g}^{2}\right.\end{array}$ & $\mathrm{sd}_{\mathrm{p}}$ \\
\hline $\mathrm{K}$ & $\mathrm{K}$ & 160 & 12.3 & 2.7 & 11.5 & 3.9 & 94 & 49.4 & 15.4 & 31.6 & 2.7 \\
\hline $\mathrm{H}$ & $\mathrm{H}$ & 153 & 22.5 & 4.9 & 17.9 & 10.0 & 80 & 49.8 & 11.4 & 42.5 & 3.7 \\
\hline $\mathrm{H}$ and K & & & & & & & & & & & \\
females & $\mathrm{HK}$ & 272 & 16.8 & 6.3 & 14.6 & 8.2 & 88 & 49.6 & 13.8 & 36.4 & 6.2 \\
\hline HK females & $F S 1$ & 105 & $18.6^{\mathrm{a}}$ & 2.8 & $17.6^{\mathrm{a}}$ & 5.0 & 95 & $49.9^{\mathrm{a}}$ & 10.8 & $36.5^{\mathrm{a}}$ & 3.1 \\
& $C 1$ & 109 & $18.7^{\mathrm{a}}$ & 3.1 & $18.2^{\mathrm{ab}}$ & 4.3 & 97 & $52.0^{\mathrm{a}}$ & 9.8 & $35.7^{\mathrm{a}}$ & 3.1 \\
& $R 1$ & 109 & $19.1^{\mathrm{a}}$ & 3.3 & $18.8^{\mathrm{b}}$ & 3.8 & 99 & $51.9^{\mathrm{a}}$ & 11.2 & $35.7^{\mathrm{a}}$ & 3.1 \\
\hline FS 1 & $F S 2$ & 104 & $16.0^{\mathrm{a}}$ & 5.0 & $14.6^{\mathrm{a}}$ & 6.6 & 92 & $49.4^{\mathrm{a}}$ & 12.8 & $36.5^{\mathrm{a}}$ & 3.0 \\
$\mathrm{C} 1$ & $C 2$ & 80 & $17.8^{\mathrm{b}}$ & 3.5 & $16.0^{\mathrm{a}}$ & 6.3 & 94 & $48.4^{\mathrm{a}}$ & 11.3 & $37.5^{\mathrm{b}}$ & 3.0 \\
$\mathrm{R} 1$ & $R 2$ & 113 & $17.9^{\mathrm{b}}$ & 3.9 & $17.6^{\mathrm{b}}$ & 4.6 & 98 & $52.9^{\mathrm{b}}$ & 13.1 & $36.7^{\mathrm{ab}}$ & 3.7 \\
\hline
\end{tabular}

Different superscripts indicate significance at $\mathrm{p}<0.05$ between groups within generations.

ranged from $88 \%$ (HK) to $99 \%$ (R1), with a trend that the FFM was reduced with an increased level of inbreeding for the FS1-R1 and FS2-R2 groups. Few pups were stillborn, the mean percentage NBA at birth within each group ranged from $97.2\left(\mathrm{sd}_{\mathrm{p}}=9.07\right)$ to $98.4\left(\mathrm{sd}_{\mathrm{p}}=5.91\right)$ (not presented in the table).

Table II gives the effect of $\mathrm{IB}_{\mathrm{T}}$ and $\mathrm{IB}_{\mathrm{F}}$ of the dams on NBA (analysed by both Model 1 and 2). As can be seen from the table, a large significant negative effect of $\mathrm{IB}_{\mathrm{F}}$ of the dam on NBA was found when $\mathrm{IB}_{\mathrm{T}}$ was already included in the model (Model 1). BWM was found to increase the mean number of pups born alive by $0.28( \pm 0.05)$ pups per 1 gram increase in the body weight of the dam. Including the trait BWM in the model resulted in slightly changed estimates, and a non-significant negative effect of $\mathrm{IB}_{\mathrm{F}}$ of the dam (Model 2, Tab. II). When $\mathrm{IB}_{\mathrm{T}}$ was analysed separately in both models, the estimate was possibly larger compared to when both $\mathrm{IB}_{\mathrm{F}}$ and $\mathrm{IB}_{\mathrm{T}}$ were included in the models.

Including all animals that were mated and did not produce a litter resulted in a larger and significantly negative effect of $\mathrm{IB}_{\mathrm{F}}$ for both Model 1 and Model 2 (NBAM, Tab. II). Also, the estimates of $\mathrm{IB}_{\mathrm{F}}$ analysed separately were larger compared to when females that did not produce a litter were excluded from the analyses. No effect of inbreeding on sex ratio could be found in the present study. 
Table II. The regression coefficients of the effect of total inbreeding $\left(\mathrm{IB}_{\mathrm{T}}\right)$ and fast created inbreeding $\left(\mathrm{IB}_{\mathrm{F}}\right)$ with standard errors (se) on the number of pups born alive (NBA) and NBA per exposed female (NBAM) analysed without body weight (Model 1) and with body weight (Model 2) in the model. The results are given as a change in the mean NBA per $10 \%$ increase in the inbreeding coefficient of the dam.

\begin{tabular}{llllll}
\hline & & \multicolumn{2}{c}{ Model 1 } & \multicolumn{2}{c}{ Model 2 } \\
\cline { 3 - 6 } & & Estimate & se & Estimate & se \\
\hline NBA & $\mathrm{IB}_{\mathrm{T}}$ & -0.31 & 0.21 & $-0.48^{* *}$ & 0.22 \\
& $\mathrm{IB}_{\mathrm{F}}$ & $-0.57 * *$ & 0.28 & -0.42 & 0.27 \\
& & & & & \\
& $\mathrm{IB}_{\mathrm{T}}$ only & $-0.63^{* *}$ & 0.15 & $-0.72^{* *}$ & 0.16 \\
\hline \multirow{2}{*}{ NBAM } & $\mathrm{IB}_{\mathrm{T}}$ & -0.37 & 0.29 & -0.45 & 0.29 \\
& $\mathrm{IB}_{\mathrm{F}}$ & $-0.95^{* *}$ & 0.37 & $-0.90^{* *}$ & 0.37 \\
& & & & & \\
& $\mathrm{IB}_{\mathrm{T}}$ only & $-0.91^{* *}$ & 0.21 & $-0.97 * *$ & 0.21 \\
\hline
\end{tabular}

** Indicates significance at $\mathrm{p}<0.05$.

The effects of $\mathrm{IB}_{\mathrm{F}}$ and $\mathrm{IB}_{\mathrm{T}}$ on $\mathrm{BW} 21$ and $\mathrm{BW} 42$ are given in Table III (Model 3). $\mathrm{IB}_{\mathrm{T}}$ of the dam has been found to have a small negative effect on BW21. No effect of $\mathrm{IB}_{\mathrm{F}}$ on BW21 could be found. For the trait BW42, no significant effect of $\mathrm{IB}_{\mathrm{F}}$ or $\mathrm{IB}_{\mathrm{T}}$ was found when both traits were included in the model. The effect of $\mathrm{IB}_{\mathrm{T}}$ was small but significantly negative when only $\mathrm{IB}_{\mathrm{T}}$ was included in the model. A model based on the inbreeding of the offspring instead of the inbreeding of the dam was also analysed for the trait BW42, but the effect of inbreeding of the offspring was found to be non-significant also when only $\mathrm{IB}_{\mathrm{T}}$ was included in the model (results not presented). The BWM of the dam was found to increase the BW21 and BW42 by $1.4( \pm 0.2)$ and $2.6( \pm 0.4)$ grams per 1 gram increase in BWM, respectively.

The $\mathrm{IB}_{\mathrm{T}}$ of the dam was found to reduce the BWM by $0.27( \pm 0.24)$ grams and $\mathrm{IB}_{\mathrm{F}}$ was found to increase the BWM by $0.48( \pm 0.20)$ grams per $10 \%$ increase in the inbreeding coefficient.

\section{DISCUSSION}

This study was designed to evaluate the effect of total versus fastly created inbreeding on litter size and body weights. In the present study, the effects of fastly created inbreeding $\left(\mathrm{IB}_{\mathrm{F}}\right)$ of the dam were found to be almost twice as large as the effects of total inbreeding $\left(\mathrm{IB}_{\mathrm{T}}\right)$ of the dam on NBA and NBAM 
Table III. The effect of total inbreeding $\left(\mathrm{IB}_{\mathrm{T}}\right)$ and fast created inbreeding $\left(\mathrm{IB}_{\mathrm{F}}\right)$ on body weights at three (BW21) and six (BW42) weeks of age with standard errors (se). The results are given as a change in the mean body weight (in grams) per $10 \%$ increase in the inbreeding coefficient.

\begin{tabular}{llll}
\hline & & Estimate & se \\
\hline BW21 & $\mathrm{IB}_{\mathrm{T}}$ & $-0.38^{* *}$ & 0.08 \\
& $\mathrm{IB}_{\mathrm{F}}$ & -0.04 & 0.09 \\
& & & \\
& $\mathrm{IB}_{\mathrm{T}}$ only & $-0.35^{* *}$ & 0.06 \\
\hline BW42 & $\mathrm{IB}_{\mathrm{T}}$ & -0.17 & 0.16 \\
& $\mathrm{IB}_{\mathrm{F}}$ & -0.20 & 0.21 \\
& & & \\
& $\mathrm{IB}_{\mathrm{T}}$ only & $-0.29^{* *}$ & 0.11 \\
\hline
\end{tabular}

** Indicates significance at $\mathrm{p}<0.05$.

Table IV. Inbreeding depression measured as a percentage of the initial litter size.

\begin{tabular}{lccc}
\hline Reference & Initial litter size & $\begin{array}{c}\text { Inbreeding } \\
\text { depression* }\end{array}$ & $\begin{array}{c}\text { Inbreeding } \\
\text { depression* as a \% } \\
\text { of initial litter size }\end{array}$ \\
\hline Bowman and Falconer [4] & 8 & 0.59 & 7.4 \\
McCarthy [25] & 9.2 & 0.46 & 5 \\
Holt et al. [16] & 16 & 0.9 & 5.6 \\
The present study** & 16.8 & 0.42 & 2.5 \\
\hline
\end{tabular}

* Expressed as a decrease in litter size per $10 \%$ increase in the inbreeding depression. ** $\mathrm{IB}_{\mathrm{F}}$, Model 2, Table II.

(except NBA analysed by Model 2), but large standard errors caused some of the estimates to be non-significant.

Several studies have concluded earlier that inbreeding has a negative effect on litter size $[6,11,20,25]$, with one exception [2]. The estimated effects of $\mathrm{IB}_{\mathrm{T}}$ on NBA in the present study ( $\mathrm{IB}_{\mathrm{T}}$ only, Tab. II) are slightly larger than the estimates presented in previous studies (Tab. IV). From earlier generations in line $\mathrm{H}$ and line $\mathrm{K}$, estimates of the reduction in NBA per $10 \%$ increase in the inbreeding coefficient of the dam were found to be $0.86( \pm 0.19)$ in line $\mathrm{H}$ and $0.67( \pm 0.42)$ in line $\mathrm{K}[17]$. These estimates are in the range of the estimates found in the present study, but the results are not directly comparable because 
the animals used in the present study are based on a cross of the $\mathrm{H}$ and the $\mathrm{K}$ lines.

If the inbreeding depression in litter size affects in biological terms the survival of a relative proportion of the potential litter, inbreeding depression could be expressed as a percentage of the average litter size of a line without inbreeding. This is done in Table IV. Based on the numbers presented in this study, the new inbreeding would only reduce the litter size by $2.5 \%$ of the original litter size. At that scale, our values, which seem at first glance higher than those from the literature, are actually lower, since our litter size was much larger. This could support the hypothesis that after a process of slowly accumulated inbreeding, the effect of fast inbreeding seems to be smaller.

The HK cross in the present study is made of two lines with a high level of inbreeding. The rate of inbreeding in the two lines has varied from 0.3-1.2 per generation [17]. This variation in the rate of inbreeding is due to a variation in the number of breeding females over the 120 generations. The reason for the lower total level of inbreeding in the $\mathrm{H}$ line compared to the $\mathrm{K}$ line is an introduction of some new animals to the $\mathrm{H}$ line in generation 20. Also, crossing of several high lines increased the effective population size in the $\mathrm{H}$ line.

Previous studies have indicated an effect of the inbreeding history on the inbreeding depression $[13,19]$. When the rate of inbreeding is low, natural selection has more time to act, and inbreeding depression should be lower compared to when a higher rate of inbreeding is practised [11]. Also, if the population size is small, natural selection has a greater chance to purge partially recessive deleterious alleles from the population because mutant allele frequencies may be reduced more effectively by selection than in large randomly mating populations [9]. In the HK cross in the present study, based on two lines kept for 124 generations, many deleterious alleles might already have been purged from the population. Fast inbreeding starting off from lines with low initial inbreeding will therefore possibly show more depression due to new inbreeding. The selection history of the lines in the present study could also probably lead to a reduced inbreeding depression. The reason for this is that selection for fertility probably is different to another selection for a quantitative trait since one selects presumably against inbreeding depression in fitness.

In the present study, a very small decline in body weights caused by total inbreeding was found for BW21, while no significant effect of newly created inbreeding on the trait could be detected. The estimated effects of new and total inbreeding on BW42 were also small. A negative effect of inbreeding on 
body weight was reported by Bünger and Hill [5] and Beilharz [2], but was not found by McCarthy [25] or Holt et al. [16]. The lack of an inbreeding effect on body weights may be associated with the fact that a reduction of litter size in inbred mice leads to an improved environment for the young, which again may cancel out the genetic effect on body size due to inbreeding [28]. The reason why maternal inbreeding was found to be more important than inbreeding of the animal itself on body weights at six weeks of age might be that the maternal inbreeding affecting body weights at three weeks of age is also important for BW42.

Estimates of inbreeding depression can be confounded with the unrelated effects of selection and drift in the experimental population [23]. Consecutive generations of full-sib mating (as are often used in inbreeding studies) can be especially problematic because of the parallel increase in the inbreeding level, the effect of genetic drift and the response to selection through generations in the population studied. The complex breeding structure in the present study produced a wide range of inbreeding levels within each generation. Also, because an animal model was used for the analyses, the effect of generation could be separated from the effect of the inbreeding level and the effect of selection.

The results in the present study have revealed a possible larger effect of newly created inbreeding compared to old inbreeding on the traits NBA and NBAM. These results demonstrate the importance of separating the effects of ancestral inbreeding from the effects of newly created inbreeding. The result that new inbreeding gives more depression than old inbreeding has some important implications: 1) The rate of inbreeding seems more important for inbreeding depression and for fitness than actual levels of inbreeding (since a high rate of inbreeding implies a lot of new inbreeding, whereas high levels of inbreeding may be due to a lot of old inbreeding, implying not so much inbreeding depression); 2) Avoidance of matings between close relatives may resolve most of the inbreeding depression / fitness problems; 3) A detailed study of the relationship between the "age of inbreeding" and the depression may reveal how much new inbreeding is acceptable and thus what rates of inbreeding are acceptable in a population.

\section{ACKNOWLEDGEMENTS}

The authors would like to thank S. Pal for all of her help with the experiment. The Norwegian Research Council granted the present study. 


\section{REFERENCES}

[1] Bataillon T., Kirkpatrick M., Inbreeding depression due to mildly deleterious mutations in finite populations: size does matter, Genet. Res. 75 (2000) 75-81.

[2] Beilharz R.G., The effect of inbreeding on reproduction in mice, Anim. Prod. 34 (1982) 49-54.

[3] Bijlsma R., Bundgaard J., van Putten W.F., Environmental dependence of inbreeding depression and purging in Drosophila melanogaster, J. Evol. Biol. 12 (1999) 1125-1137.

[4] Bowman J.C., Falconer D.S., Inbreeding depression and heterosis of litter size in mice, Genet. Res. 1 (1960) 262-274.

[5] Bünger L., Hill W.G., Inbred lines of mice derived from long-term divergent selection on fat content and body weight, Mamm. Gen. 10 (1999) 645-648.

[6] Chai C.K., Characteristics in inbred mouse populations plateaued by directional selection, Genetics 54 (1966) 743-753.

[7] Charlesworth D., Charlesworth B., Inbreeding depression with heterozygote advantage and its effect on selection for modifiers changing the outcrossing rate, Evolution 44 (1990) 870-888.

[8] Charlesworth B., Charlesworth D., The genetic basis of inbreeding depression, Genet. Res. 4 (1999) 329-340.

[9] Charlesworth D., Morgan M.T., Charlesworth B., Inbreeding depression, genetic load and the evolution of outcrossing rates in a multi-locus system with no linkage, Evolution 44 (1990) 1469-1489.

[10] Day S.B., Bryant E.H., Meffert L.M., The influence of variable rates of inbreeding on fitness, environmental responsiveness and evolutionary potential, Evolution 57 (2003) 1314-1324.

[11] Ehiobu N.G., Goddard M.E., Taylor J.F., Effect of rate of inbreeding on inbreeding depression in Drosophila melanogaster, Theor. Appl. Genet. 77 (1988) 123-127.

[12] Falconer D.S., Mackay T.F.C., Introduction to Quantitative Genetics, 4th edn., Longman, UK, 1996.

[13] Fernàndez A., Rodrigàñez J., Toro M.A., Rodrìguez M.C., Siliò L., Inbreeding effects on parameters of the growth function in three strains of Iberian pigs, Journ. Anim. Sci. 80 (2002) 2267-2275.

[14] Gilmour A.R., Cullis B.R., Welham S.J., Thompson R., ASREML Reference Manual, in: NSW Agriculture Biometric Bulletin No. 3., NSW Agriculture: Locked Bag 21, Orange, NSW, 2800, Australia, 1999, p. 210.

[15] Holt M., Selection for litter size in mice; correlated responses in body weight, Master thesis, Department of Animal Science, Agricultural University of Norway, PO. box 5025, N-1432 Ås, Norway, 2001.

[16] Holt M., Nicholas F.W., Moran C., James J.W., Martin I.C.A., Development of a highly fecund inbred strains of mice, Mamm. Gen. 15 (2004) 951-959.

[17] Holt M., Vangen O., Meuwissen, T., Long-term responses, changes in genetic variances and inbreeding depression from 122 generations of selection on increased litter size in mice, Journ. Anim. Breed. Gen. 122 (2005) 199-209. 
[18] Joakimsen Ø., Baker R.L., Selection for litter size in mice, Acta Agric. Scand. 7 (1977) 301-318.

[19] Lacy R.C., Ballou J.D., Effectiveness of selection in reducing the genetic load in populations of Peromyscus polionotus during generations of inbreeding, Evolution 52 (1998) 900-909.

[20] Lacy R.C., Alaks G., Walsh A., Hierarchical analysis of inbreeding depression in Peromyscus polionotus, Evolution 50 (1996) 2187-2200.

[21] Lande R., Schemske D.W., The evolution of self-fertilization and inbreeding depression in plants. I. Genetic models, Evolution 39 (1985) 24-40.

[22] Latta R., Ritland K., The relationship between inbreeding depression and prior inbreeding among populations of four Mimulus taxa, Evolution 48 (1994) 806-817.

[23] Lynch M., Design and analyses of experiments on random drift and inbreeding depression, Genetics 120 (1988) 791-807.

[24] Margulis S.W., Relationships among parental inbreeding, parental behaviour and offspring viability in Oldfield mice, Anim. Behav. 55 (1998) 427-438.

[25] McCarthy J.C., The effects of inbreeding on the components of litter size in mice, Genet. Res. 10 (1967) 73-80.

[26] Pray L.A., Goodnight C.J., Genetic variation in inbreeding depression in the red flour beetle Trilobium castaneum, Evolution 49 (1995) 176-188.

[27] Reed D.H., Lowe E.H., Briscoe D.A., Frankham R., Inbreeding and extinction: Effects of rate of inbreeding, Cons. Gen. 4 (2003) 405-410.

[28] Roberts R.C., The effect on litter size of crossing lines of mice inbred without selection, Genet. Res. 1 (1960) 239-252.

[29] Vangen O., Results from 40 generations of divergent selection for litter size in mice, Livest. Prod. Sci. 37 (1993) 197-211.

[30] Vangen O., Long term selection for litter size in mice (>100 generations); correlated responses and biological constraints, GPh 5.1, in: The 50th Annual Meeting of the European Association for Animal Production, 22-26 August 1999, Zürich, p. 10.

[31] Wang J., Hill W.G., Charlesworth D., Charlesworth B., Dynamics of inbreeding depression due to deleterious mutations in small populations: mutation parameters and inbreeding rate, Genet. Res. Camb. 74 (1999) 165-178.

[32] Whitlock M.C., Selection, load and inbreeding depression in a large metapopulation, Genetics 160 (2002) 1191-1202. 